\title{
Relationship between the Ligand Structure of Copper and the Stability of Superoxide Dismutase
}

\author{
Jun-ichi KaJihara, Mitsuo Enomoto, Kazuo Katoh, \\ Keiichi Mitsuta* and Masahiro KoHNo* \\ Research Laboratories, Pharmaceuticals Group Nippon Kayaku Co., Ltd., \\ 3-31-12 Shimo, Kita-ku, Tokyo 115, Japan \\ * ESR Group Application Lab., Technical and Engineering Division, \\ JEOL Ltd., 1418 Nakagami, Akishima, \\ Tokyo 196, Japan
}

Received August 25, 1989

\begin{abstract}
The ligand structure of chelated copper in recombinant human $\mathrm{Cu}_{2} \mathrm{Zn}_{2} \mathrm{SOD}$ (r-hSOD) and its metal-substituted SODs was examined. In r-hSOD the configuration of the copper binding site was axially symmetrical and that of metal-substituted SODs had a tendency to change towards a tetrahedral type compared with r-hSOD except for $\mathrm{Cu}_{2}(\mathrm{VO})_{2} \mathrm{SOD} . \mathrm{Cu}_{2}(\mathrm{VO})_{2} \mathrm{SOD}$ was not tetrahedral and in this case the ligand atom of copper was inclined to convert from nitrogen towards oxygen. In $\mathrm{Cu}_{2} \mathrm{E}_{2} \mathrm{SOD}, \mathrm{Ag}_{2} \mathrm{Cu}_{2} \mathrm{SOD}$, and $\mathrm{Cu}_{2}(\mathrm{VO})_{2} \mathrm{SOD}$ the specific activities were lower but in $\mathrm{Cu}_{2} \mathrm{Cu}_{2} \mathrm{SOD}$ and $\mathrm{Cu}_{2} \mathrm{Co}_{2} \mathrm{SOD}$ they were nearly identical with that of r-hSOD. These results suggested the ligand structure of chelated copper was not related to the specific activity of SOD. However, these SODs were less stable than r-hSOD against heat treatment and denaturing reagent. Further they were less stable against attack by an inactivator (hydrogen peroxide) except for $\mathrm{Cu}_{2}(\mathrm{VO})_{2} \mathrm{SOD}$. In this case the decreased stability of these SODs was associated with the change of the ligand structure of copper from that of r-hSOD. These results suggested that the presence of zinc contributed highly to the stable formation of the ligand structure of copper and the enzymic stability.
\end{abstract}

Superoxide dismutase (SOD) catalyzes the dismutation of superoxide anion radicals and has been found in a variety of organisms. ${ }^{1,2}$ ) SOD is a metalloprotein classified according to the metal ion, including $\mathrm{Fe}, \mathrm{Mn}$, or $\mathrm{Cu}$, which is necessary for SOD activity. ${ }^{3)}$ Bovine and human $\mathrm{Cu}_{2} \mathrm{Zn}_{2}$ SOD are dimeric enzymes, made of $16 \mathrm{~K}$ identical subunits, each containing $\mathrm{Cu}(\mathrm{II})$ and $\mathrm{Zn}(\mathrm{II})$ ion. ${ }^{4)} \mathrm{Cu}(\mathrm{II})$ is important in the catalytic cycle, ${ }^{5}$ while $\mathrm{Zn}$ (II) stabilizes the protein structure. Study of the ligand structure of bovine $\mathrm{Cu}_{2} \mathrm{Zn}_{2} \mathrm{SOD}$ (b-SOD) has been done by electron spin resonance (ESR), ${ }^{6,7)}$ nuclear magnetic resonance (NMR), ${ }^{8,9)}$ and $\mathrm{X}$-ray crystallography. ${ }^{10)}$ The $\mathrm{Cu}(\mathrm{II})$ is coordinated to four histidines $(44,46,61$, and 118$)$, one (his 61) of which it shares with the $\mathrm{Zn}(\mathrm{II})$ ion. The zinc is also bonded to two additional histidines (69 and 78) and aspartic acid $(81){ }^{10}{ }^{\circ}$ The geometry around the $\mathrm{Cu}$ is a slightly distorted square plane while $\mathrm{Zn}$ is at the center of a distorted tetrahedron. ${ }^{10)}$ The copper is also reported to have a coordinated water molecule. ${ }^{12)}$ The ESR properties of b-SOD and its various metal-substituted derivatives has been extensively investigated. ${ }^{11-13)}$ In this report we examined the ligand structure of chelated copper in several metal-substituted SODs prepared from recombinant human $\mathrm{Cu}_{2} \mathrm{Zn}_{2} \mathrm{SOD}(\mathrm{r}-\mathrm{hSOD})$ and the relationship between that ligand structure and the specific activity or the stability of SOD activity was investigated.

\section{Materials and Methods}

Recombinant human $\mathrm{Cu}_{2} \mathrm{Zn}_{2} \mathrm{SOD}$ ( $\mathrm{r}-\mathrm{hSOD}$ ) was cloned and expressed in $E$. coli. ${ }^{14}$ It was then highly purified by the method of McCord and Fridovich. ${ }^{1}$ Apo-SOD was prepared by the method of Weser et al. ${ }^{15}$ The metalsubstituted SODs were prepared by dialysis against buffer solutions containing metal ions as follows: 


\begin{tabular}{|c|c|c|}
\hline Type of SOD & $\begin{array}{l}\text { Starting } \\
\text { materials }\end{array}$ & Dialyzed buffer \\
\hline $\mathrm{Cu}_{2} \mathrm{Cu}_{2} \mathrm{SOD}$ & Apo-SOD & $\begin{array}{l}1 \mathrm{mM} \mathrm{CuSO} / 0.2 \mathrm{M} \\
\text { acetate buffer }(\mathrm{pH} 6.0)\end{array}$ \\
\hline $\begin{array}{l}\mathrm{Cu}_{2} \mathrm{E}_{2} \mathrm{SOD} \\
(\mathrm{E}=\text { empty })\end{array}$ & Apo-SOD & $\begin{array}{l}\mathrm{I} \mathrm{mM} \mathrm{CuSO}_{4} / 0.1 \mathrm{M} \\
\text { acetate buffer }(\mathrm{pH} 3.8)\end{array}$ \\
\hline $\mathrm{Cu}_{2} \mathrm{Co}_{2} \mathrm{SOD}$ & $\mathrm{Cu}, \mathrm{E}-\mathrm{SOD}$ & $\begin{array}{l}1 \mathrm{mM} \mathrm{CoCl}_{2} / 0.1 \mathrm{M} \mathrm{K}- \\
\text { phosphate buffer } \\
(\mathrm{pH} \mathrm{7.4)}\end{array}$ \\
\hline $\mathrm{Cu}_{2}(\mathrm{VO})_{2} \mathrm{SOD}$ & $\mathrm{Cu}, \mathrm{E}-\mathrm{SOD}$ & $\begin{array}{l}1 \mathrm{mM} \mathrm{VOSO}_{4} / 0.1 \mathrm{M} \\
\text { acetate buffer }(\mathrm{pH} 5.4)\end{array}$ \\
\hline $\mathrm{Ag}_{2} \mathrm{Cu}_{2} \mathrm{SOD}$ & Apo-SOD & $\begin{array}{l}\text { (1st) } 1 \mathrm{~mm} \mathrm{AgNO}_{3} / 0.1 \mathrm{M} \\
\text { acetate buffer }(\mathrm{pH} 3.8) \\
\text { (2nd) } 1 \mathrm{~mm} \text { CuSO } \\
\text { phosphate buffer } \\
\text { (pH } 7.4 \text { ) }\end{array}$ \\
\hline
\end{tabular}

The resulting metal-substituted SOD solutions were exhaustively dialyzed against deionized distilled water. Amounts of incorporated metals were measured by X-ray fluorescence. SOD activity assays were done as described by McCord and Fridovich, ${ }^{1}$ using the xanthine-xanthine oxidase system. Protein concentrations were measured by the method of Lowry et al. ${ }^{16)}$ with bovine serum albumin (BSA) as a standard. ESR measurements were done with a JEOL FE-1XG spectrometer with a temperature controller, and analyzed with a computer system (ESPRIT23). X-ray fuorescence was measured on a Gieger flex IKF-3064 (Rigaku Denki, Co, Japan).

\section{Results and Discussion}

ESR spectra are shown in Fig. 1 and ESR parameters are shown in Table I. ESR parameters of $\mathrm{r}$-hSOD were obtained as $(\mathrm{g} / / 2.265$, $\mathrm{A} / / 0.0143 \mathrm{~cm}^{-1}$ ) and these values agreed well with those of native human and bovine $\mathrm{Cu}_{2} \mathrm{Zn}_{2}$ SOD. ${ }^{18-23)}$ In this case the ligand structure was estimated to be an axially symmetric type as reported before. Broadened hyperfine splitting patterns of copper in $\mathrm{Cu}_{2} \mathrm{E}_{2} \mathrm{SOD}, \mathrm{Cu}_{2}(\mathrm{VO})_{2} \mathrm{SOD}$, and $\mathrm{Cu}_{2} \mathrm{Co}_{2} \mathrm{SOD}$ indicated that the absence of zinc induced instability in the ligand structure of copper. The spectrum of $\mathrm{Cu}_{2} \mathrm{Cu}_{2} \mathrm{SOD}$ was nearly a single peak. This suggests that an interaction between two coppers occurs at the metal binding site. The configurations of copper binding site were estimated based on the model of Yokoi et al. ${ }^{24)}$ (Fig. 2).

In $\mathrm{r}$-hSOD the configuration of the copper
Table I. Specific Activity and ESR Spectral PARAMETERS OF $\mathrm{Cu}_{2} \mathrm{Zn}_{2}$ SOD AND METAL-SUBSTITUTED SOD

\begin{tabular}{lccc}
\hline Type of SOD & $\begin{array}{l}\text { Specific } \\
\text { activity } \\
(\mathrm{U} / \mathrm{mg})\end{array}$ & $\mathrm{g} / /$ & $\mathrm{A} / /\left(\mathrm{cm}^{-1}\right)$ \\
\hline & 3660 & 2.265 & 0.0143 \\
$\mathrm{Cu}_{2} \mathrm{Zn}_{2} \mathrm{SOD}$ & 2680 & 2.277 & 0.0138 \\
$\mathrm{Cu}_{2} \mathrm{E}_{2} \mathrm{SOD}$ & 3560 & 2.289 & 0.0128 \\
$\mathrm{Cu}_{2} \mathrm{Cu}_{2} \mathrm{SOD}$ & 3620 & 2.301 & 0.0121 \\
$\mathrm{Cu}_{2} \mathrm{Co}_{2} \mathrm{SOD}$ & 1760 & 2.346 & 0.0131 \\
$\mathrm{Cu}_{2}(\mathrm{VO})_{2} \mathrm{SOD}$ & 670 & 2.316 & 0.0108 \\
$\mathrm{Ag}_{2} \mathrm{Cu}_{2} \mathrm{SOD}$ & & & \\
\hline
\end{tabular}

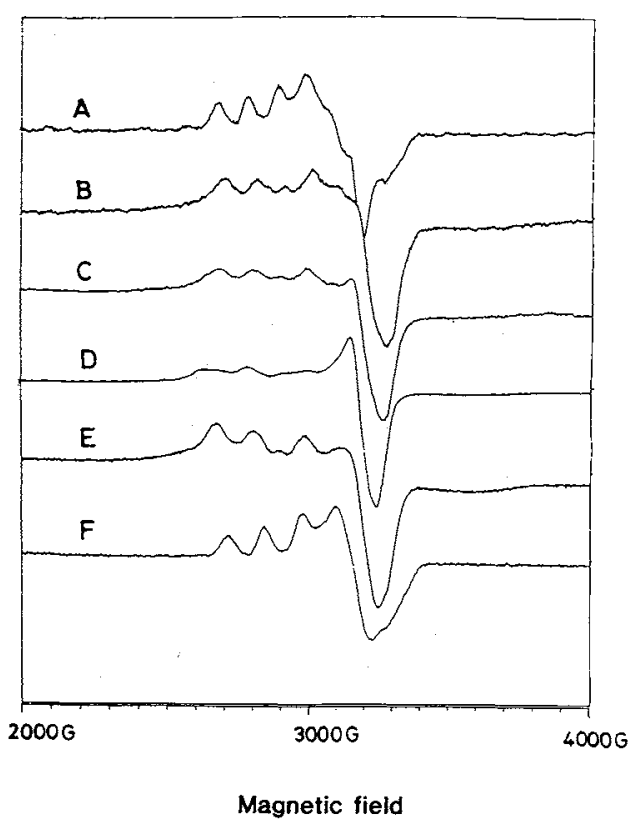

Fig. 1. ESR Spectra of $\mathrm{Cu}_{2} \mathrm{Zn}_{2} \mathrm{SOD}$ and Its Metalsubstituted SODs.

A, $\mathrm{Ag}_{2} \mathrm{Cu}_{2} \mathrm{SOD} ; \mathrm{B}, \mathrm{Cu}_{2}(\mathrm{VO})_{2} \mathrm{SOD} ; \mathrm{C}, \mathrm{Cu}_{2} \mathrm{Co}_{2} \mathrm{SOD} ; \mathrm{D}$, $\mathrm{Cu}_{2} \mathrm{Cu}_{2} \mathrm{SOD} ; \mathrm{E}, \mathrm{Cu}_{2} \mathrm{E}_{2} \mathrm{SOD} ; \mathrm{F}, \mathrm{Cu}_{2} \mathrm{Zn}_{2} \mathrm{SOD}$

All samples were dissolved in $25 \mathrm{~mm}$ potassium phosphate buffer ( $\mathrm{pH} 7.4)$ and measured at $173 \mathrm{~K}$.

Instrument settings: microwave power, 4 milliwatts; modulation amplitude, $6.3 \mathrm{G}$; time constant, $0.1 \mathrm{sec}$; scan rate, $500 \mathrm{G}$ per $\mathrm{min}$.

binding site was an axially symmetric type. That of metal-substituted SOD had a tendency to change towards a tetrahedral type compared with $\mathrm{r}$-hSOD except for $\mathrm{Cu}_{2}(\mathrm{VO})_{2} \mathrm{SOD}$. $\mathrm{Ag}_{2} \mathrm{Cu}_{2} \mathrm{SOD}$ in particular shifted to a tetrahedral type (Fig. 2, E). This suggested the copper chelated in the zinc site was typically 


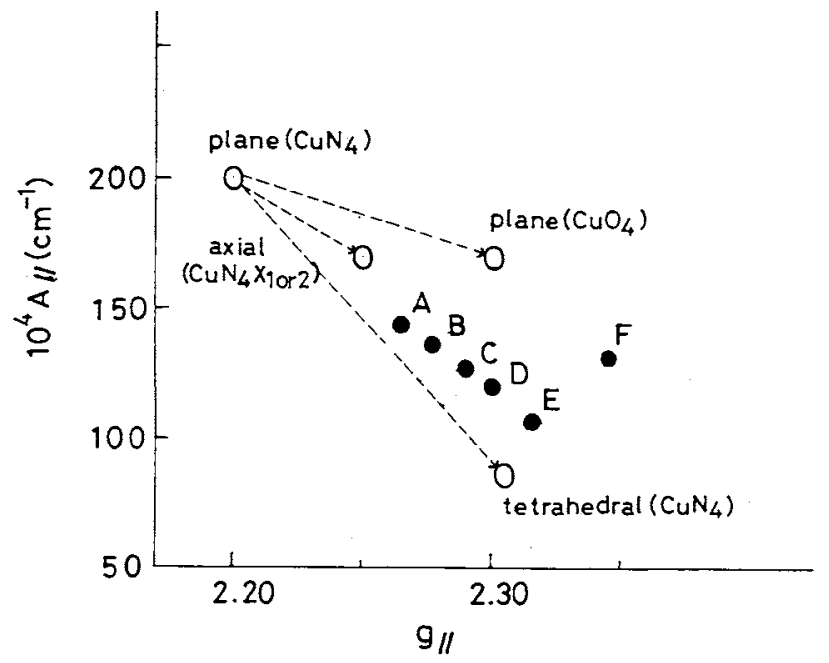

Fig. 2. Ligand Structure of Recombinant $\mathrm{Cu}_{2} \mathrm{Zn}_{2} \mathrm{SOD}$ and Its Metal-substituted SODs Estimated from ESR Parameters.

A, $\mathrm{Cu}_{2} \mathrm{Zn}_{2} \mathrm{SOD} ; \mathrm{B}, \mathrm{Cu}_{2} \mathrm{E}_{2} \mathrm{SOD} ; \mathrm{C}, \mathrm{Cu}_{2} \mathrm{Cu}_{2} \mathrm{SOD} ; \mathrm{D}, \mathrm{Cu}_{2} \mathrm{Co}_{2} \mathrm{SOD} ; \mathrm{E}, \mathrm{Ag}_{2} \mathrm{Cu}_{2} \mathrm{SOD} ; \mathrm{F}, \mathrm{Cu}_{2}(\mathrm{VO})_{2} \mathrm{SOD}$.

tetrahedral and this result is consistent with that of the bovine SOD derivative. ${ }^{13,25)}$ In this SOD a little activity $(18 \%$ or r-hSOD) remained. In this case the decreased activity was out of all relation to the ligand structure of copper because the copper site was occupied by $\mathrm{Ag}$. In contrast, however, $\mathrm{Cu}_{2}(\mathrm{VO})_{2} \mathrm{SOD}$ was not a tetrahedral type. With this SOD, the ligand atom of copper was inclined to convert from nitrogen towards oxygen (Fig. 2, F) and it may suggest that this change contributes to the low specific activity $(1760 \mathrm{U} / \mathrm{mg})$ of this SOD (Table I).

In $\mathrm{Cu}_{2} \mathrm{E}_{2} \mathrm{SOD}$ the specific activity was $73 \%$ of $r-h S O D$. This suggests that the chelation of zinc contributes to the increase of the activity. In $\mathrm{Cu}_{2} \mathrm{Cu}_{2} \mathrm{SOD}$ and $\mathrm{Cu}_{2} \mathrm{Co}_{2} \mathrm{SOD}$ the specific activities were nearly identical to that of $\mathrm{r}$ hSOD. These results suggested that the ligand structure of chelated copper was not related to the specific activity of SOD. Next the relationship between the ligand structure of copper and the stability of these SODs except for $\mathrm{Ag}_{2} \mathrm{Cu}_{2} \mathrm{SOD}$ was examined, comparing them with r-hSOD. $\mathrm{Ag}_{2} \mathrm{Cu}_{2} \mathrm{SOD}$ was excluded because copper was not chelated in the copper binding site. The stability against heat treatment $\left(100^{\circ} \mathrm{C}, 1 \mathrm{~min}\right)$ and the denaturing re- agent $(1 \%$ SDS $)$ are summarized in Fig. 3 . The heat treatment reduced the activity of these SODs, but r-hSOD was more stable than the others (remaining activity: $73 \%$ in r-hSOD, $42 \%$ in $\mathrm{Cu}_{2} \mathrm{Cu}_{2} \mathrm{SOD}, 34 \%$ in $\mathrm{Cu}_{2} \mathrm{Co}_{2} \mathrm{SOD}$, $17 \%$ in $\mathrm{Cu}_{2} \mathrm{E}_{2} \mathrm{SOD}$, and $8 \%$ in $\mathrm{Cu}_{2}$ (VO) ${ }_{2} \mathrm{SOD}$ ). R-hSOD was also more stable than the others against SDS treatment (remaining activity: $48 \%$ in $\mathrm{r}-\mathrm{hSOD}, 4 \%$ in $\mathrm{Cu}_{2} \mathrm{Cu}_{2} \mathrm{SOD}, 34 \%$ in $\mathrm{Cu}_{2} \mathrm{Co}_{2} \mathrm{SOD}, 2 \%$ in $\mathrm{Cu}_{2} \mathrm{E}_{2} \mathrm{SOD}$, and $5 \%$ in $\left.\mathrm{Cu}_{2}(\mathrm{VO})_{2} \mathrm{SOD}\right)$. $\mathrm{Cu}_{2} \mathrm{Co}_{2} \mathrm{SOD}$ was somewhat stable against SDS and this result was confirmed by activity staining after SDS-polyacrylamide gel electrophoresis. ${ }^{17)}$ Second, the effects of inhibitors on SOD activity were examined. Hydrogen peroxide is an inhibitor which attacks the ligand of copper in SOD. Most of the SODs were inactivated by this reagent (final conc. $3 \mathrm{~mm}$ ), but $\mathrm{r}-\mathrm{hSOD}$ was more stable (remaining activity: $40 \%$ in $\mathrm{r}$-hSOD, $11 \%$ in $\mathrm{Cu}_{2} \mathrm{Cu}_{2} \mathrm{SOD}, 16 \%$ in $\mathrm{Cu}_{2} \mathrm{Co}_{2} \mathrm{SOD}$, and $13 \%$ in $\mathrm{Cu}_{2} \mathrm{E}_{2} \mathrm{SOD}$ ) (Fig. 4). Surprisingly only $\mathrm{Cu}_{2}(\mathrm{VO})_{2} \mathrm{SOD}$ was resistant to the hydrogen peroxide. This may be associated with the change of the ligand atom from nitrogen to axygen in this SOD. Sodium azide competitively inhibits the superoxide anion binding 


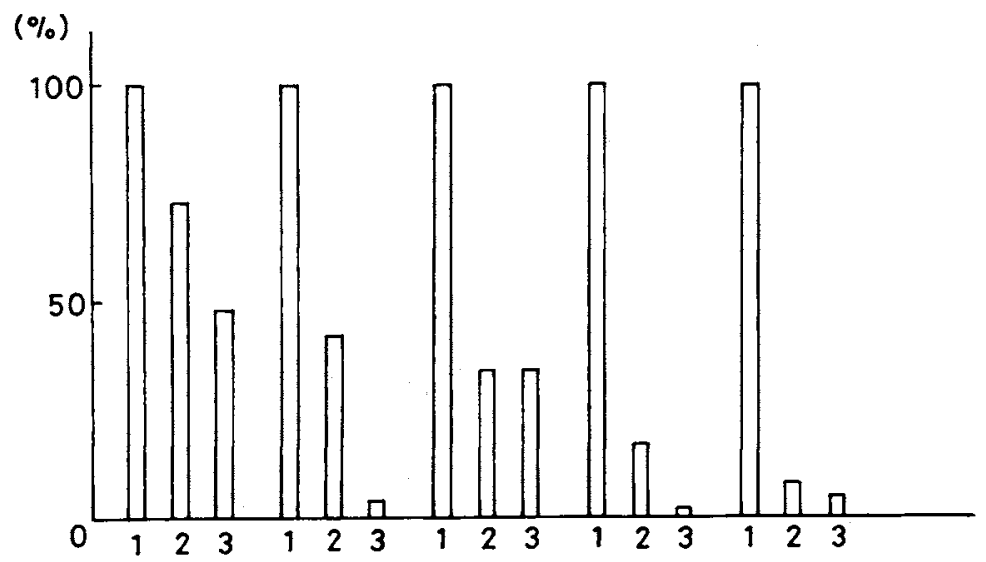

Fig. 3. The Stability of SODs Against Heat Treatment and SDS Treatment. (from the left): $\mathrm{Cu}_{2} \mathrm{Zn}_{2} \mathrm{SOD}, \mathrm{Cu}_{2} \mathrm{Cu}_{2} \mathrm{SOD}, \mathrm{Cu}_{2} \mathrm{CO}_{2} \mathrm{SOD}, \mathrm{Cu}_{2} \mathrm{E}_{2} \mathrm{SOD}, \mathrm{Cu}_{2}(\mathrm{VO})_{2} \mathrm{SOD}$. 1 , no treatment; 2 , heat treatment $\left(100^{\circ} \mathrm{C}, 1 \mathrm{~min}\right) ; 3$, SDS treatment (final conc. $1 \% \mathrm{SDS}$, at room temperature for $30 \mathrm{~min}$ ).

In these treatment $500 \mathrm{U} / \mathrm{ml}$ of each SOD solution was used. The value of percentage indicates the remained activity when the value of no treatment is fixed as $100 \%$.

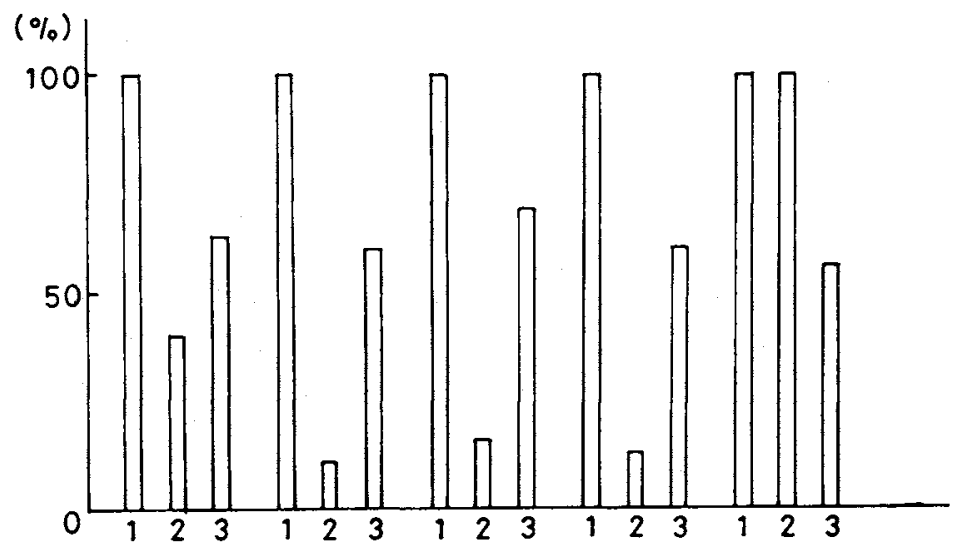

Fig. 4. The Stability of SODs against Inhibitors.

(from the left): $\mathrm{Cu}_{2} \mathrm{Zn}_{2} \mathrm{SOD}, \mathrm{Cu}_{2} \mathrm{Cu}_{2} \mathrm{SOD}, \mathrm{Cu}_{2} \mathrm{Co}_{2} \mathrm{SOD}, \mathrm{Cu}_{2} \mathrm{E}_{2} \mathrm{SOD}, \mathrm{Cu}_{2}(\mathrm{VO})_{2} \mathrm{SOD}$.

1 , no addition; 2 , addition of hydrogen peroxide (final conc. $3 \mathrm{~mm}$ ); 3 , addition of sodium azide (final conc. $0.1 \%$.

Hydrogen peroxide was added to $500 \mathrm{U} / \mathrm{ml}$ of each SOD solution and after $10 \mathrm{~min}$. SOD activity was measured. Sodium azide was added to the reaction mixture containing about $10 \mathrm{U}$ of each SOD and SOD activity was measured. The value of percentage indicates the remained activity when the value of no addition is fixed as $100 \%$.

to the copper site of SOD molecule. ${ }^{11)}$ The degree of inhibition by this reagent (final conc. $0.1 \%$ ) was almost identical in all SODs (Fig. 4). This suggested the effect of sodium azide was out of all relation to the ligand structure of copper. R-hSOD was more stable than the others against the heat treatment and SDS treatment, and further more stable against the attack by hydrogen peroxide except for $\mathrm{Cu}_{2}(\mathrm{VO})_{2} \mathrm{SOD}$. In these SODs CD spectra were nearly identical and it was suggested the secondary or tertially structure was almost identical. ${ }^{17)}$ These results suggested the different stability in these SODs did not derive 
from the difference of secondary or tertially structure but from the difference of the ligand structure of chelated copper. In these SODs the decreased stability was associated with the change of the ligand structure of copper from that of r-hSOD. These considerations suggest that the presence of zinc contributes highly to the stable formation of the ligand structure of copper and the enzymic stability.

\section{References}

1) J. M. McCord and I. Fridovich, J. Biol. Chem., 244, 6049 (1969).

2) 1. Fridovich, Adv. Enzymol., 41, 35 (1974).

3) J. A. Fee, "Metal Ions in Biological Systems," Vol. 13, ed. by H. Sigel, Marcel Dekker, New York, 1981, p. 259.

4) R. J. Carrico and H. F. Deutsch, J. Biol. Chem., 245, 723 (1970).

5) D. Klug-Roth, I. Fridovich and J. Rabin, J. Am. Chem. Soc., 95, 2786 (1973).

6) R. A. Kieberman, R. H. Sands and J. A. Fee, J. Biol. Chem., 257, 336 (1982).

7) J. A. Fee, J. Peisach and W. B. Mims, J. Biol. Chem, 256, 1910 (1981).

8) I. Bertini and G. Lanini, J. Am. Chem. Soc., 107, 4391 (1985).

9) N. Boden, M. C. Holmes and P. F. Knowles, Biochem. Biophys. Res. Commun., 57, 845 (1974).

10) J. Richardson, K. A. Thomas, B. H. Rubin and D. C. Richardson, Proc. Natl. Acad. Sci. U.S.A., 72, 1349
(1975).

11) K. G. Strothkamp and S. J. Lippard, Biochemistry, 20, 7488 (1981).

12) J. A. Fee, J. Biol. Chem., 248, 4229 (1973).

13) K. M. Beem, D. C. Richardson and K. V. Rajagopalan, Biochemistry, 16, 1930 (1977).

14) T. Morino, M. Morita, K. Seya, Y. Sukenaga, K. Katoh and T. Nakamura, Appl. Microbiol. Biotechnol., 28, 170 (1988).

15) U. Weser and H. J. Hartmann, Febs Lett., 17, 78 (1971).

16) O. H. Lowry, N. J. Rosebrough, A. L. Farr and R. J. Randall, J. Biol. Chem., 193, 265 (1951).

17) J. Kajihara, M. Enomoto, K. Nishijima, M. Yabuuchi and K. Katoh, J. Biochem., 104, 851 (1988).

18) G. Rotilio, L. Calabrese, D. Bossa, A. Finazzi Agra and B. Mondovi, Biochemistry, 11, 2182 (1972).

19) K. M. Beem, W. E. Rich and K. V. Rajagopalan, $J$. Biol. Chem., 249, 7298 (1974).

20) R. Bray, S. Cockle, M. Fielden, P. Roberts, G. Rotilio and L. Calabrese, Biochem. J., 139, 43 (1974).

21) M. Fielden, P. Roberts, R. Bray, D. Lowe, G. Mautner, G. Rotilio and L. Calabrese, Biochem. J., 139, 49 (1974).

22) G. Rotilio, L. Morpurgo, C. Giouagnoli, L. Calabrese and B. Mondovi, Biochemistry, 11, 2187 (1972).

23) G. B. Robert and A. F. James, Biochim. Biophys. Acta, 537, 86 (1978).

24) H. Yokoi, Kagaku Sohsetsu (in Japanese), 20, 6310 (1978).

25) M. W. Pantoliano, J. S. Valentine and L. A. Nafie, $J$. Am. Chem. Soc., 104, 6310 (1982). 